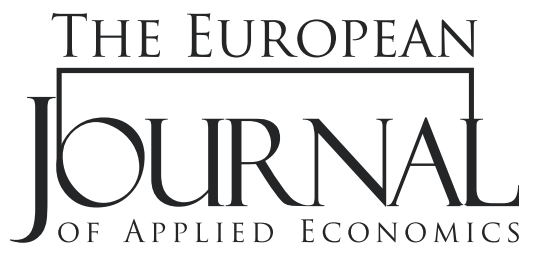

\title{
THE EXPLANATORY FACTORS OF SOVEREIGN CREDIT DEFAULT SWAPS SPREADS: A QUANTILE REGRESSION APPROACH
}

Radhia Zemirl*, Mohand Chitti

Faculty of Economics,

Department of Business and Management, University Mouloud Mammeri of Tizi-Ouzou, People's Democratic Republic of Algeria

\section{Abstract:}

This article aims to analyze the main risk factors that explain the manifestation and the aggravation of sovereign risk, particularly through the dynamics of sovereign CDS spreads in euro area member countries. The explanatory factors that will be analyzed are related to general risk aversion, which is explained by the volatility of the stock markets, liquidity risk perceived by the flight to quality phenomenon, idiosyncratic risk, which is explained by the deterioration of the state of macroeconomic fundamentals. We will adopt an econometric approach with the quantile regression method applied to panel data developed by Canay (2011), because it allows to estimate the effect of the independent variables on the different regions of the distribution, of the dependent variable and also makes it possible to overcome the problem of the presence of extreme values. Finally, our model has made it possible to identify, over time and different countries, the factors which significantly explain a sovereign risk, and whose deteriorated situation is likely to lead to payment defaults, which is very important to know, especially in the current unfavorable macroeconomic context. These include the volatility of the stock markets, which shows investor mistrust, the drying up of liquidity in the bond markets, which explains the phenomenon of flight to quality, the budgetary factor, which is explained by the unsustainable debt, and the economic factor, perceived by the level of wealth of a country.

\section{Article info:}

Received: April 10, 2020

Correction: May 12, 2020

Accepted: June 29, 2020

\section{Keywords:}

CDS spreads;

Sovereign risk;

Fundamentals;

Risk aversion;

Quantile regression. 


\section{INTRODUCTION}

Before the international financial crisis and the crisis of the euro area, the risk of default of a state was mentioned only in the case of emerging countries, the default of a developed country is implausible. However, the international financial crisis of 2007 and the crisis of the euro area have shown that the risk of default of a sovereign borrower is well conceivable in developed economies, especially European countries. Indeed, because of the convergence criteria required by the Maastricht Treaty for members of the euro area, investors paid little attention to the economic indicators and debt of the countries of this union. Investor awareness of this risk began with the outbreak of the 2007 crisis, and has intensified as the crisis has turned into a euro area crisis. In recent years (mainly since 2010), investors' perception of sovereign default risk in the euro area has changed from one country to another.

The causes of this credit event are various, and can be trigged by the unsustainability of sovereign debt, a budget deficit, a commercial deficit, systemic crises (banking, stock market, foreign exchange or economic, etc.) leading to a phenomenon of contagion and an increase in international borrowing costs in the capital markets.

Our work has its origins in the aggravation of sovereign risk in the euro area, which has resulted in the unsustainability of sovereign debt, and the risk of exclusion from the financial markets. This deterioration in credit quality was also accompanied by a rise in the sovereign bond yield, an increase in the CDS premium, and an unfavorable revision of the sovereign rating by rating agencies.

These facts lead us to ask a crucial question around which this work is articulated, namely: "What are the main explanatory factors of sovereign CDS spreads in the euro area?"

In this work, we will consider the sovereign CDS spread as a measure of the default risk of a public borrower. This spread plays a major role in determining the default risk, and is a pertinent measure of the estimated solvency of investors, as clarified by Afonso et al. (2012), De Santis (2012), and Aizenman et al. (2013), who argue in favor of this indicator as a better measure of sovereign risk.

Thus, this article aims to determine the main risk factors that explain the manifestation of sovereign risk, particularly through the dynamics of sovereign CDS spreads in the euro area member countries. The explanatory factors that will be analyzed are related to general risk aversion, liquidity, and macroeconomic and macro-financial fundamentals idiosyncratic to countries. The originality of this article is that it measures sovereign risk across sovereign CDS spreads by examining various explanatory variables linked to the volatility of European stock markets, the phenomenon of flight to liquidity, and is linked to the state of fundamentals, over a period of crisis and lull period extending from 2007 to 2018 . In addition, a comparative analysis between the member countries of the euro area characterized by economic vulnerability and resilience has been added in order to understand the factors which explain the aggravation of sovereign risk in these countries, which is important to know both for policymakers and for investors, especially in the current unfavorable macroeconomic context caused by the health crisis due to Covid-19, which may cause the surge in public debt. We also use an original approach to the analysis of panel data by quantile regressions, a rich method, that above all allows us to take into account the strong individual heterogeneity and the presence of extreme values. This is a plus for our study, especially since the previous work used only the classic panel data method.

Thus, we will conduct an analysis of panel data by exploiting the two sources of variation in statistical information: temporal and individual, in order to determine the main risk factors that have an impact on sovereign CDS spreads. More particularly, we resort to the quantile regression method applied to 
panel data developed by Canay (2011), which allows us to estimate the effect of the independent variables on the different regions of the distribution, notably the quantiles, of the dependent variable and not on its average only. In other words, this technique describes how the conditional quantiles change as a function of these determinants, and also make it possible to overcome the problem of the presence of extreme values.

To achieve the objective of this article and provide elements of answers to the problem posed, this article will be divided into two parts. In the first point, we will review the existing literature on the explanatory factors of sovereign CDS spreads to explain the correlations between the sovereign CDS spread and the common and idiosyncratic risk factors. The second point will focus on the econometric study in which we will present our sample and the period of our study, after which we will introduce the variables of the dynamics of the chosen of sovereign CDS spreads and, finally, we will examine the results of the classic regressions and quantile regressions of our model by highlighting the main determinants of the spread of CDS sovereign. Moreover, we will analyze the results of the comparison between the results of the quantile regressions of the panel of vulnerable countries versus robust countries of the euro area by highlighting the main explanatory factors of the sovereign CDS spreads of these two groups of countries.

\section{LITERATURE REVIEW}

\section{ON THE EXPLANATORY FACTORS OF SOVEREIGN DEFAULT RISK}

First of all, it seems important to review the existing literature on sovereign spreads by presenting a theoretical overview of the links between these spreads and their explanatory factors by referring to the previous works dealing with this topic.

The choice to analyze this relationship can be justified, in particular, by the fact that there has been some uncertainty recently in advanced countries about a possible sovereign default, and this is why studies have started to develop, especially in the case of the countries of the euro area, contrary to the studies of the emerging countries, characterized by a considerable sovereign risk in the 1990s.

Interest in the risk of sovereign default in euro area countries has emerged over the past decade following the outbreak of the 2007 international financial crisis in the US housing market and its transmission to European public bond markets.

Overall, the number of studies on the determinants of sovereign spreads has increased substantially in recent years. In addition, the existing economic literature on explanatory factors for sovereign spreads in euro area countries, among others, has been given to attribute the volatility sovereign spreads to three major factors, namely: the overall risk factor or common risk, the specific risk factor or idiosyncratic risk, and the risk of contagion.

Indeed, the analyses carried out in this direction, notably by Kalbaska (2013), Heinz and Sun (2014), Zeman (2014), Artus and Rodado (2012), Manganelli and Wolswijk (2009), Attinasi et al. (2009), Afonso, et al. (2012, 2015), Ertugrul and Ozturk (2013), Ordonez-Callamand et al. (2017), Arellano el al. (2017), Debarsy et al. (2018), Chaumont (2018), Mpapalika and Malikane (2019), used different methodologies and chose different explanatory variables to explain these spreads. However, it is important to emphasize that the majority of authors have convergent conclusions showing the importance of common and idiosyncratic risk factors in determining CDS spreads and sovereign bond yields of euro area countries. In addition to these factors, some studies have revealed the existence of 
a contagion effect within these countries, which may play a major role in the spread of risk factors from one country to another and, consequently, in the increase or widening of their spreads as a result of deteriorating fundamentals and increased risk aversion in the markets, for example: Afonso, et al. (2012, 2015), Lizarazo (2013), Artus and Rodado (2012). In what follows, we will attempt to clarify these factors relating to the aforementioned risks by looking at previous work.

First, "the common risk factor" is related to the general perception of international risk by investors. It is generally considered a risk factor common to all countries because it described how economic agents perceive risk and react simultaneously to a risky situation. There are several methods for measuring risk perception in the financial markets. One example is a method that compares the current levels of different financial assets that are representative of how agents perceive risks (spreads on government bonds, volatility in financial markets, stock or exchange rate fluctuations, ...) with their historical evolution to deduce an aggregate index of risk perception, as demonstrated especially by Afonso et al. (2012, 2015), Kilponen et al. (2015). In addition, for the measurement of this type of risk, Heinz and Sun (2014), Artus and Rodado (2012), Gerlash et al. (2010), Afonso et al. (2015) use the implied volatility of the S\&P500 Index (VIX). This index, which is widely used in work related to sovereign spreads, is seen as a gauge of investors' level of fear, as it reflects their degree of risk aversion, which tends to increase during periods of uncertainty turbulence. De Santis (2012) uses BBB-rated private bond yields, while Niehof (2014) expresses this corporate spread by the yield spread of a low-rated and a low-rated private bond. Allegret et al. (2016) analyze this risk from a VSTOXX index (measuring the volatility of European stock markets), and examine the Impact of the euro area crisis on European banks from this index. Overall, the effect of global risk on the dynamics of sovereign spreads is heterogeneous. It has been more pronounced during periods of stress in the global financial markets, and more pronounced in countries with high levels of public debt, and this result has been demonstrated through the aforementioned works.

Second, "the idiosyncratic risk factor" reflects the probability of default of a sovereign borrower, which depends on the state of macroeconomic and macro-financial fundamentals, reflecting the ability of a sovereign country to honor its financial commitments. According to Beyond Ratings, the idiosyncratic risk assessment for a sovereign country is largely based on indicators taken into account in the country risk analysis, in particular the country's economic performance, as well as the many risks that could have an impact on its growth potential in the short and long term. Indeed, investors in sovereign bonds monitor several types of risks, often grouped into four pillars: economic growth, public finances, external risks, and socio-political stability. The most-used indicators for measuring such risk in empirical studies are the variables that represent the country's public finances, including the ratio (Budget Balance/GDP and Public Debt/GDP), to assess the sustainability of public finances and its impact on sovereign bond yields, as seen through the work of Artus and Rodado (2012), Castelletti Font and Ben Salem (2017), Costantini et al. (2014), Afonso et al. (2015), Hatchondo et al. (2017). Indeed, a deterioration of the budget deficit is an indicator of the country's fiscal vulnerability.

Furthermore, other macroeconomic and macro-financial fundamentals have been illustrated by several observations, namely:

-the economic growth of a country is part of the macroeconomic fundamentals that would reflect the level of default risk. This may be represented by the GDP growth rate, the volume of industrial production (that provides information on the ability to repay its debt), or foreign exchange reserves (which are also considered as indicators of a country's wealth). 
- the unemployment rate, which reflects on the overall health of a country, as a high rate of unemployment can have a negative impact on a country's growth potential and fiscal position, since a high level of unemployment forces countries to pay unemployment benefits, which can weigh heavily on a country's budget.

- the inflation rate is an essential indicator of macroeconomic stability, as a very high inflation can also be a way to fail, as demonstrated by Aizenman et al. (2016), Artus and Rodado (2012).

- the real effective exchange rate, since an unfavorable change in this rate corresponds to a deterioration in the country's competitiveness that leads to low production, which will negatively affect the state's revenue - this indicator was used by Artus and Rodado (2012), Tsoukalas and Arghyrou (2011).

In addition, other indicators were used for the assessment of idiosyncratic risk, such as the rating of rating agencies used by Artus and Rodado (2012), Manganelli and Wolswijk (2009) and De Santis (2012), as a reference of the probability of default of an issuer.

Third, "the contagion risk factor" is actually the result of the conjunction of the first two risks. Contagion is materialized by investors changing views about a country's solvency (its ability to repay debt), which further increases the cost of borrowing by more expensive premiums, making the debt of the most vulnerable states, with weak fundamentals, unsustainable. Caceres and Unsal (2011) used a principal component analysis (PCA) applied to risk premiums to identify a common factor in their evolution and in order to show the correlation existing between the variables. The assumption behind this approach is that the returns of different securities are correlated because they depend on one or more common factors. Other studies, like Afonso et al. (2012, 2015), Artus and Rodado (2012), Longstaff et al. (2011), also attempted to quantify the contagion effect using PCA. These authors have revealed that the recent dynamics of sovereign spreads have shown the existence of a dichotomy between countries of the euro area, the most powerful northern countries, and those in the most vulnerable south. Although the rise in sovereign spreads was in both groups, it was more pronounced for the southern countries compared to the period before the sovereign debt crisis, confirming the existence of a contagion effect between these groups of countries.

Based on the literature review presented above, the objective of the next point is to highlight empirical evidence of the importance of the impact of common risk factors and idiosyncratic risk on the probability of default of a Sovereign state. However, we will omit the risk of contagion, which is supposed to be the subject of another study with other methods of analysis.

\section{DATA AND METHODOLOGY}

This study will focus on the use of the panel data method to estimate the main determinants of sovereign risk in the euro area.

By referring to this technique, we can exploit the two sources of variation in statistical information: temporal (or intra-individual variability) and individual (or inter-individual variability). This makes it possible to take into account the dynamics of behaviors and the heterogeneity that can exist between individuals (some member countries of the euro area in our case). It also makes it possible to have a large number of observations through the use of the temporal and individual dimension. 


\section{Model Estimation}

Through the panel data method, we will study the existing relationship between sovereign CDS spreads and these different explanatory variables.

The model is written as follows:

$$
\log C D S \text { spreads }=\alpha i+\beta 1 \text { Bond }+\beta 2 \text { Vstoxx }+\beta 3 \text { Debit }+\beta 4 \text { Blance }+\beta 5 \text { Reer }+\beta 6 \text { Prod }+\varepsilon i, t
$$

Where: Sovereign CDS spread with 5-year maturity (expressed in Log) is the dependent variable, and the explanatory variables are: Bond is the long term government bond yields, Vstoxx is the volatility index of the European stock markets, Balance represents the budget balance/GDP, Debt is the level of the public debt/GDP, Reer is the real effective exchange rate, Prod is the growth of industrial production.

Our model takes into account a sample of 10 euro area member countries, namely: Germany, France, Belgium, Finland, the Netherlands, Austria, Ireland, Spain, Italy, and Portugal, with an annual periodicity ranging from 2007 to 2018.

As a result, we will obtain a number of observations of 480 (10countries X 12years X 4quarters). This appreciable number of observations makes it possible to guarantee a better accuracy of the estimators, to reduce the risks of multicollinearity, and especially to widen the field of investigation.

\section{Description of the Variables}

The selected variables are those most commonly used in the literature for the explanation of sovereign spreads. We have chosen a specification consisting of six explanatory variables, including macroeconomic and macro-financial fundamentals (budget balance, public debt, industrial production, real effective exchange rate), and two market variables, including "Vstoxx" for risk aversion and government bond yields for liquidity risk.

\section{- The Dependent Variable "Sovereign CDS spreads with 5-year maturity"}

For the assessment of the sovereign default risk in our analysis, we selected the sovereign CDS spread of euro area member countries. The latter reflects the risk of default as anticipated by the market. Its price includes a premium of risk, liquidity, and counterpart, that tend to overreact in case of systemic shock. Thus, CDS spreads play a major role in determining the risk of default, and are a good measure of the estimated solvency of investors. The higher the spread, the less solvent the country.

Several authors argue in favor of this indicator as a better measure of sovereign risk, including Barrios et al. (2009), Afonso et al. (2012), De Santis (2012) and Aizenman et al. (2013).

The maturity of CDS 5-year was chosen because it is the most liquid asset on the markets compared to other maturities.

In addition, we have added the logarithm option to our variable to be explained in order to linearize it, and reduce the strong individual heterogeneity concerning this variable.

\section{- The Independent Variables}

Vstoxx: is the market volatility index of the Eurostoxx50, an index that includes the 50 largest capitalizations on the euro area financial markets. It is calculated according to the same principles as the VIX (its American counterpart), which would allow an immediate comparison of the nervousness between the different markets. The Vstoxx reflects the feeling of fear in the market, hence the nickname "the indicator of fear in the euro area." When the Vstoxx is high, it means that the market is volatile 
and that investors will have to pay higher risk premiums (for the next 30 days). Analyzing a factor that reflects international risk aversion as a common factor is imperative to examine sovereign risk in the region, which is generally measured by uncertainty in the financial markets, hence, the selection of the variable "Vstoxx" for its quantification.

Long-term Government Bond Yields: is representative of the liquidity risk, or the phenomenon of "flight to quality" or "flight to liquidity," which designates a situation where investors seek to sell assets perceived as risky, and to buy non-risky assets, by seeking liquidity on these safe investments. This causes a surge in yields on the riskiest assets and the related risk premiums and, consequently, an imbalance in the credit market in reaction to an increase in volatility. This phenomenon that notably increases the sovereign or government bond yields generate a drying up of liquidity on risky assets of countries considered insolvent, and thus becomes unsustainable debt, from whence the strong manifestation of sovereign risk.

The Budget Balance and the Public Debt: the budget balance/GDP report is widely used to measure the sustainability of public finances, and informs investors about the country's default risk (i.e., the risk that the sovereign state cannot meet its obligations in time and entirely because the repayment capacity of a country depends on its ability to generate financial resources to cover the debt service). Similarly, for the public debt/GDP ratio, which also assesses the country's fiscal position, a higher debt should increase the risk of sovereign default, and hence the return demanded by investors. We therefore expect a positive relationship between the public debt/GDP ratio and the CDS spread. Moreover, we expect a negative sign between the budgetary balance/GDP and the sovereign CDS spread, because an improvement in this balance (i.e., an increase in the surplus or a decrease in the deficit) will lower the CDS spread.

The Growth of Industrial Production: measures the impact of the robustness of the countries of the euro area on the sovereign risk. Thus, an increase or decrease in this variable indicates an increase or decrease in the country's economic performance, which in turn has an effect on the creditworthiness of a country opposite these creditors, implying a volatility of sovereign CDS spreads more or less important from one country to another. We expect a negative correlation between this variable and CDS premiums.

The Real effective Exchange Rate (Reer): refers to this rate as a measure of the level of external competitiveness. This indicator represents the evolution of the currency of a country in relation to all exchange rates of its main trading partners while taking into account the weight of each one. In this regard, it should be noted that the difference between the inflation rates of the euro area countries is taken into account, hence the choice of the real effective exchange rate, which takes into account the weighted average of the currencies of the main partners (adjusted inflation differentials). A drop in this rate corresponds to an improvement in the country's external competitiveness or price-competitiveness, which leads to high production in order to support the increase in exports, which will generate a balance of trade surplus. This will result in a sustained budget balance and debt level due to the large inflows of foreign currency and, therefore, lower interest rates on government bonds and less volatile CDS spreads. For that, we expect a positive correlation between the Reer and the sovereign CDS spreads.

It should be noted, in this regard, that the explanatory variables used in this study have also been the subject of previous analyses. The expected signs of their correlation with sovereign CDS spreads are summarized in Table 1: 
Table 1- Presentation of the Variables and Expected Signs.

\begin{tabular}{|c|c|c|c|}
\hline & Designation & Data source & $\begin{array}{l}\text { Expected signs on } \\
\text { CDS spreads }\end{array}$ \\
\hline \multicolumn{4}{|c|}{ Dependent variable } \\
\hline CDS Spreads & $\begin{array}{l}\text { The risk premium of sovereign CDS with 5-year } \\
\text { maturity }\end{array}$ & Datastream & \\
\hline \multicolumn{4}{|c|}{ Independent variables } \\
\hline Balance & Budget balance as $\%$ of GDP & Eurostat & - \\
\hline Debt & Public debt as $\%$ of GDP & Eurostat & + \\
\hline Vstoxx & Volatility index on the market of Eurostoxx 50 & Datastream & + \\
\hline Bond & Long-term government bond yield (10 years) & Eurostat & + \\
\hline Reer & Real effective exchange rate & Eurostat & + \\
\hline Prod & The growth of industrial production & Oecd.org & - \\
\hline
\end{tabular}

Source: Designed by authors.

\section{Analysis of Econometric Study Test Results}

Before analyzing the results of the regressions, it is important to respect a number of conditions, namely: the overall and partial significance of the model, and the existence of multicollinearity, heteroscedasticity and autocorrelation, which can bias the coefficients of the regressions in panel data.

To verify this, the analysis of certain tests of the panel data method is needed to verify the robustness of the model.

First, we begin by analyzing the correlation matrix in order to judge the existence of multicollinearity, which is a problem that occurs when the explanatory variables tend to demonstrate and/or measure the same phenomenon, i.e., indicate whether the selected variables generate a redundant effect or not.

Table 2 represents the correlation matrix that makes it possible to measure the relationship between the dependent variable and the explanatory variables and between the explanatory variables themselves, as well as the intensity of the relationship (correlation):

Table 2- Correlation Matrix

\begin{tabular}{|c|c|c|c|c|c|c|c|}
\hline & Log CDS & Balance & Debt & Reer & Bond & Prod & Vstoxx \\
\hline $\log$ CDS & 1.0000 & & & & & & \\
\hline Balance & -0.4678 & 1.0000 & & & & & \\
\hline Debt & 0.4294 & -0.1599 & 1.0000 & & & & \\
\hline Reer & -0.0575 & 0.0100 & -0.1640 & 1.0000 & & & \\
\hline Bond & 0.6896 & $-0,3787$ & 0.0981 & -0.0136 & 1.0000 & & \\
\hline Prod & -0.3938 & 0.3903 & 0,0935 & -0.0134 & -0.2409 & 1.0000 & \\
\hline Vstoxx & 0.2496 & -0.1221 & -0.1864 & 0.0195 & 0.2948 & -0.1261 & 1.0000 \\
\hline
\end{tabular}

Source: Constructed from database exploitation under Stata 15 software. 
As we can see from this table, there is a relationship between the different variables selected. The correlation between these values is acceptable, and the explanatory variables are weakly correlated in our analysis. This indicates the absence of a multicollinearity problem.

We also use another approach to confirm these results and further prove the absence of multicollinearity, especially the VIF (Variance Inflation Factor) test, which estimates how much the variance of a coefficient is increased due to a linear relationship with other predictors. If all VIFs are equal to 1 and/or close to 1 , there is no multicollinearity.

However, some authors believe that there really is a problem of multicollinearity when VIF is higher than 2.5 , while others worry only from 5 .

In our case, the results of the test in Table 3 show that all the coefficients are close to 1 , which signifies the absence of multicollinearity, indicating the correct choice of variable.

Table 3- Multicollinearity Test Results (VIF Test)

\begin{tabular}{ccc}
\hline Variable & VIF & 1/VIF \\
\hline Balance & 1.33 & 0.751069 \\
\hline Debt & 1.12 & 0.894717 \\
\hline Reer & 1.03 & 0.971961 \\
\hline Bond & 1.28 & 0.779607 \\
\hline Prod & 1.20 & 0.832425 \\
\hline Vstoxx & 1.16 & 0.860467 \\
\hline Mean VIF & 1.19 & \\
\hline
\end{tabular}

Source: Constructed from database exploitation under Stata 15 software.

Moreover, we must determine whether the data series are stationary, as in the set of empirical analyzes that consider strictly stationary processes. We will demonstrate stationarity by means of the specified test namely the unit root test, in this case, the Levin test, Lin \& Chu (LLC).

Table 4- The Results of the Unit Root Test (LLC Test)

\begin{tabular}{ccc}
\hline & \multicolumn{2}{c}{ Test LLC } \\
\cline { 2 - 3 } & At the level & At first difference \\
\hline Log CDS & 0,2037 & $0.0412^{* *}$ \\
\hline Balance & $0,0000^{* * *}$ & - \\
\hline Debt & $0,0021^{* * *}$ & - \\
\hline Bond & 0,5519 & - \\
\hline Prod & $0,0088^{* * *}$ & - \\
\hline Reer & $0,0347^{* *}$ & - \\
\hline Vstoxx & $0,0000^{* * *}$ & -
\end{tabular}

NB: If the $\mathrm{P}$-values are less than $0.01 ; 0.05 ; 0.1$. This means that the variables are stationary at the $1 \% * * *, 5 \%$ $* *, 10 \% *$ threshold, respectively.

Source: Constructed from database exploitation under Stata 15 software. 
Through the stationarity test of LLC, where the null hypothesis assumes that all series are non-stationary against the alternative hypothesis that the series are stationary, we notice that the variables are almost all stationary at level, except for the two variables Log CDS and Bond, which becomes stationary at first difference at the threshold of 5\%. These results are good, quality indicators of our variables and/or our panel.

It should be noted that after verifying stationarity, we continued the classic approach of the panel data method, namely, the estimation of the regressions with fixed and random effects models. As a reminder, the random effects panel model assumes independence between the unobservable individual effects and the explanatory variables, while the fixed effects model hypothesizes the correlation between the individual effects and the observable factors. Therefore, the fixed-effects model is more used in the empirical literature, because it applies better to economic phenomena.

Subsequently, we realized the Hausman test in order to choose between these two models. This test revealed that our panel is a fixed effects model because the probability is lower than the threshold of statistical significance of 5\%. In parallel, in order to overcome the problem of heteroscedasticity, which shows whether the error matrix is constant or not, we calculated the robust standard errors using the estimator called "Huber/White Sandwich." To obtain the robust errors, we just added the "robust" option to the "xtreg" routine of the Stata software, allowing to estimate the basic panel models and, therefore, this option has made it possible to settle any problem which arises following the presence of heteroskedasticity.

Moreover, it should be noted in this regard that the regression results of our fixed effects model cannot be validated entirely due to the existence of extreme values and strong heterogeneity of our dependent variable "sovereign CDS spread" and, to a lesser extent, the other two variables. Thus, the estimator Ordinary Least Squares (MCO) which underlies the fixed effects model would not be suitable. The presence of strong heterogeneity between individuals could induce biased coefficients. This is why it is essential to correct this problem before any interpretation and validation of the empirical results, especially if the implications in terms of public policies are significant.

One of the ways to take into account the severe heterogeneity of the dependent variable is to use a technique called quantile regression. This allows to estimate the impact of the explanatory variables on different parts (quantiles) of the distribution of the dependent variable, and not only its average. In this application, we apply the method proposed by Canay (2011). There are two reasons for this choice. First, the procedure proposed by Canay (2011) assimilates to a fixed effects model that we validated when choosing between fixed and random effects. Second, the procedure followed by Canay (2011) can be obtained simply in terms of programming by taking into account unobserved individual heterogeneity.

This quantile method applied to panel data developed by Canay (2011) makes it possible to estimate the effect of the explanatory variables on different regions of the distribution of the dependent variable. In other words, quantile regressions attempt to assess how the conditional quantiles are modified when the determinants of the dependent variable vary.

Moreover, this procedure provides more robust estimates of the coefficients linked to the explanatory variables, since the quantiles, based on a rank criterion, are less sensitive than the average to the presence of extreme values or outliers. 


\section{EMPIRICAL RESULTS AND DISCUSSION}

As a reminder, we study the sensitivity of sovereign CDS spreads to the risk aversion factor in the financial markets and the bond markets and to the state of macroeconomic and macro-financial fundamentals of euro area member countries. For this, we regress the variables deemed significant on the panel data. Table 5 presents the results of our estimates:

Table 5- Results of the Panel Estimation with Robust Fixed Effects Regressions and with Quantile Regressions

\begin{tabular}{|c|c|c|}
\hline & (1) & (2) \\
\hline & m1 & $\mathrm{m} 2$ \\
\hline VARIABLES & $\log \mathrm{CDS}$ & yhat \\
\hline \multirow[t]{3}{*}{ Balance } & -0.00421 & -0.00410 \\
\hline & $(0.00319)$ & $(0.00281)$ \\
\hline & 0.219 & 0.146 \\
\hline \multirow[t]{3}{*}{ Debt } & $0.00665^{\star *}$ & $0.00676^{* * *}$ \\
\hline & $(0.00261)$ & $(0.000389)$ \\
\hline & 0.031 & 0.000 \\
\hline \multirow[t]{3}{*}{ Reer } & 0.00253 & -0.00276 \\
\hline & $(0.0189)$ & $(0.00799)$ \\
\hline & 0.897 & 0.730 \\
\hline \multirow[t]{3}{*}{ Bond } & $0.0987^{\star * *}$ & $0.105^{* * *}$ \\
\hline & $(0.0127)$ & $(0.00548)$ \\
\hline & 0.000 & 0.000 \\
\hline \multirow[t]{3}{*}{ Prod } & $-0.0115^{\star *}$ & $-0.0115^{\star * *}$ \\
\hline & $(0.00376)$ & $(0.00116)$ \\
\hline & 0.014 & 0.000 \\
\hline \multirow[t]{3}{*}{ Vstoxx } & $0.00722^{\star \star \star}$ & $0.00571^{\star * *}$ \\
\hline & $(0.00123)$ & $(0.00141)$ \\
\hline & 0.000 & 0.000 \\
\hline \multirow[t]{3}{*}{ Constant } & 1.517 & $2.057^{\star \star}$ \\
\hline & $(2.373)$ & $(0.857)$ \\
\hline & 0.539 & 0.017 \\
\hline Observations & 480 & 480 \\
\hline R-squared & 0.624 & \\
\hline \multirow{2}{*}{$\begin{array}{l}\text { Number of country } \\
\text { Hausman test }\end{array}$} & 10 & \\
\hline & Fixed Effects & \\
\hline
\end{tabular}

In parentheses: robust standard errors

In italics: P-value

Significance threshold: $* * * \mathrm{p}<0.01, * * \mathrm{p}<0.05, * \mathrm{p}<0.1$

Source: Constructed from database exploitation under Stata 15 software. 
We will now analyze the results of the model on our data. After analyzing all the possible tests and configurations, we are interested in the impact of the common risk, liquidity risk, and idiosyncratic risk on the dynamics of sovereign CDS spreads.

First of all, the quantile regressions reveal that the common or global risk factor represented by the variable Vstoxx has a positive and significant impact, which corresponds to previous results. In other words, the volatility of the stock markets of the main European financial centers also had an impact on the sovereign CDS spreads, all the more since the quarterly frequency used detected the short-term effects and the quantiles took good account of the jump in the evolution of the variable. For example, an increase in Vstoxx index of 1\% would increase the spread of $0.00571 \%$.

Therefore, this result is also in the context of previous studies, because he joined the explanation that sovereign spreads are mainly based on an exaggerated risk aversion.

In addition, the liquidity risk represented by the bond yield has a linear relationship with the spread, and is significant. This observation suggests that an increase in public borrowing rates implies a phenomenon of flight to assets with low liquidity risk, in this case the German Bund. This reflects a contraction of liquidity in the bond market and, thus, the manifestation of liquidity risk, which causes a surge in sovereign CDS spreads. This means that the liquidity of sovereign bonds has been taken into consideration as a result of the sovereign debt crisis.

Regarding the idiosyncratic risk of each country, the variables related to budgetary factors, especially debt/GDP, is significantly positive, unlike the budget balance/GDP, which is not significant in our analysis. This last result does not meet our expectations, which shows that this indicator is not taken into consideration by international investors and, therefore, does not play a major role in the evolution of sovereign CDS spreads, unlike the variable debt.

Specifically, a $1 \%$ increase in debt would increase the spread by $0.00676 \%$. This is entirely in line with our expectations. Indeed, when a country's debt increases, its risk of default increases, investors become more suspicious and, therefore, demand a higher return and the spread increases.

It should be noted that the public imbalances of the countries deemed to be risky in the euro area have indeed played an important role in the increase in CDS spreads, especially after the international financial crisis of 2007 and during the debt crisis in the euro area. The swelling of these imbalances has indeed contributed significantly to the brutal revision of investors' expectations.

In these conditions of competitiveness, the adjustment in particular could contribute to improving the sustainability of public debt in the countries of the euro area, hence, the choice of the real effective exchange rate (Reer) as a possible determinant of variability of the sovereign CDS spread. However, in our case, the regressions reveal that there is no significant impact between the Reer and the spread and, moreover, the sign of the coefficient of this variable is negative, contrary to what we expected. Therefore, the result in our model of this variable relating to external competitiveness does not go in the direction predicted by theory. This can be explained by the strong heterogeneity of our sample, as not all individuals have the same economic structures. In fact, according to the "Lowess" test, which makes it possible to observe the distribution of individuals in a curve fitted to a cloud of point, the results revealed a quite important dispersion of countries and some of the extreme values, hence, the reason for the sign contrary to expectations.

In addition, this shows that macroeconomic variables may have different influences on spreads over time and across selected countries. 
The industrial production variable that reflects the economic performance and/or the level of wealth of a country, and appears significant and with a negative coefficient, because the countries with a growing production see their spread decrease, and it shows that the country is able to repay its debt revenue from this growth.

Therefore, this result corroborates previous studies and is according to the theory developed.

Furthermore, in addition to this analysis, we deemed it useful to divide our sample into two groups of countries: on the one hand, countries deemed vulnerable in the euro area, namely: Spain, Italy, Ireland, Portugal, and on the other hand, a group of countries considered to be particularly robust: Germany, Finland, Austria, Belgium, France, The Netherlands, and this in order to distinguish between the factors, which explain the sovereign CDS spread in two groups of characterized countries by disparities in economic structures and, therefore, which present economic vulnerability and/or resilience. The results of the regressions of the two panels with the two groups of countries are presented in Table 6:

Table 6- Results of the Panel Estimation with Robust Fixed Effects Regressions and with Quantile Regressions -Comparison Between the Panel of Vulnerable Countries and the Panel of Robust Countries-

\begin{tabular}{|c|c|c|c|c|}
\hline & \multicolumn{2}{|c|}{ Panel 1 (Vulnerable Countries) } & \multicolumn{2}{|c|}{ Panel 2 (Robust Countries) } \\
\hline & Log CDS & Yhat & Log CDS & Yhat \\
\hline \multirow[t]{3}{*}{ Balance } & -0.00155 & -0.000013 & -0.00494 & -0.00544 \\
\hline & $(0.00313)$ & $(0.00320)$ & $(0.00537)$ & $(0.00368)$ \\
\hline & 0.654 & 0.997 & 0.400 & 0.141 \\
\hline \multirow[t]{3}{*}{ Debt } & $0.00644^{\star}$ & $0.00751^{* * *}$ & $0.0219^{* *}$ & $0.0217^{\star * *}$ \\
\hline & $(0.00271)$ & $(0.000494)$ & $(0.00650)$ & $(0.000868)$ \\
\hline & 0.098 & 0.000 & 0.020 & 0.000 \\
\hline \multirow[t]{3}{*}{ Reer } & 0.0251 & $0.0266^{\star *}$ & -0.0261 & $-0.0301^{\star *}$ \\
\hline & $(0.0239)$ & $(0.0113)$ & $(0.0355)$ & $(0.0122)$ \\
\hline & 0.370 & 0.020 & 0.495 & 0.014 \\
\hline \multirow[t]{3}{*}{ Bond } & $0.110^{* * *}$ & $0.106^{\star * *}$ & $0.132^{\star *}$ & $0.133^{\star * *}$ \\
\hline & $(0.00914)$ & $(0.00692)$ & $(0.0450)$ & $(0.0217)$ \\
\hline & 0.001 & 0.000 & 0.033 & 0.000 \\
\hline \multirow[t]{3}{*}{ Prod } & $-0.00751^{\star * *}$ & $-0.00835^{\star * *}$ & -0.00840 & $-0.00731^{\star * *}$ \\
\hline & $(0.00687)$ & $(0.00134)$ & $(0.00493)$ & $(0.00238)$ \\
\hline & 0.001 & 0.000 & 0.149 & 0.002 \\
\hline \multirow[t]{3}{*}{ Vstoxx } & $0.00534^{\star * *}$ & $0.00637^{\star * *}$ & $0.00899^{\star * *}$ & $0.00922^{\star * *}$ \\
\hline & $(0.000805)$ & $(0.00206)$ & $(0.00189)$ & $(0.00252)$ \\
\hline & 0.007 & 0.002 & 0.005 & 0.000 \\
\hline \multirow[t]{3}{*}{ Constant } & -0.961 & -1.123 & 2.733 & $3.022^{\star *}$ \\
\hline & $(3.192)$ & $(1.236)$ & $(4.281)$ & (1.199) \\
\hline & 0.783 & 0.365 & 0.551 & 0.012 \\
\hline Observations & 192 & 192 & 288 & 288 \\
\hline R-squared & 0.798 & & 0.566 & \\
\hline Number of country & 4 & & 6 & \\
\hline Hausman test & Fixed effects & & Fixed effects & \\
\hline
\end{tabular}

In parentheses: robust standard errors

In italics: P-value

Significance threshold: ${ }^{* * *} p<0.01,{ }^{* *} p<0.05, * p<0.1$

Source: Constructed from database exploitation under Stata 15 software. 
Through the observation of this table we can make a comparative analysis of the explanatory factors between two distinct groups of countries. The results reveal that the factors explaining sovereign risk in the euro area are almost similar, whether for vulnerable countries with weak fundamentals or for robust countries in the euro area with economic resilience with the solidity of their fundamentals. Indeed, it appears that, unlike the budgetary balance/GDP, which is not significant for the vulnerable and robust countries, the public debt/GDP is significantly positive. This latest result is in line with our expectations, which shows that this indicator plays a key role in the evolution of sovereign CDS spreads. For example, a $1 \%$ increase in debt would increase the spread by $0.00751 \%$ for the first panel, while for the second by $0.0217 \%$, which shows that the impact of the variable debt on sovereign CDS spreads is more important in robust countries. The result is similar for the other fundamentals, namely industrial production or the Reer, which are significant for the two groups of countries; however, the sign of the variable Reer is negative in Panel 2, which is contrary to expectations.

In addition, the variables representing the common risk or the degree of risk aversion by investors, represented by the variable Vstoxx, as well as the liquidity risk or the phenomenon of flight to liquidity in our study, seem to be very determining for the calculation of sovereign CDS spreads for the two groups of countries. Investors are very attentive to the volatility of the stock and/or bond markets, that is to say that the determination of the sovereign CDS premium strongly depends on these factors, given the high significance of the variables taken into account.

In general, our model panel data has mostly coefficients with the same signs as our expectations, however, the level of impact varies depending on the type of risk.

Indeed, the result of the regressions with quantile regressions shows an increase in the importance of fundamentals in the calculation of the spread following the sovereign debt crisis. Investors have become more interested in country fundamentals, such as their debt.

The variables representing the common risk represented by the volatility of the financial markets and the liquidity risk or the refuge effect in our study are very significant and have a considerable impact on the variation of sovereign CDS spreads, which corroborates the results of previous work. However, the regressions of some variables, notably the government budget balance and the Reer, do not correspond to expectations.

\section{CONCLUSION}

The debt crisis in the euro area has demonstrated the reappearance of sovereign risk, which is confirmed by common movements in the evolution of volatility, notably on sovereign spreads suggesting the presence of a contagion effect.

In this article, we have tried to determine the main risk factors that explain the variation of sovereign CDS spreads in the euro area countries, notably that they are vulnerable or robust. The explanatory factors examined are related to general risk aversion, liquidity, and fundamentals, through a new approach, notably quantile regressions.

Our estimates show that the sovereign CDS spreads of vulnerable countries are more sensitive to risk factors than those of countries deemed to be robust. In addition, our model reveals that the independent variables are statically significant and have the expected signs with the exception of two variables. The results show, in fact, that there is a significant relationship between spreads and variables related to the budgetary factor, in particular public debt, liquidity, or risk aversion on the bond market, and the 
level of wealth of country. On the other hand, the impact of the government budget balance and Reer variables relating to idiosyncratic risk appear to be insignificant, contrary to expectations. This can be explained by the fact that investors are less sensitive to the variation of these two fundamentals, unlike the other selected indicators.

In addition, it should be noted that sovereign CDS spreads are more sensitive to risk factors after the onset of financial market stress starting in August 2007 and following the worsening of the sovereign debt crisis in 2011, which has fueled investor mistrust. This confirms the cause and effect relationship between sovereign CDS spreads and sovereign risk.

This study has, therefore, definitively raised the question of the resurgence of sovereign risk in advanced countries and identified the main explanatory factors for this risk measured by the sovereign CDS spreads, which provide relevant information. This makes it possible to present interesting implications both for policymakers and for investors, especially in the current unfavorable macroeconomic context caused in particular by a health crisis with serious consequences for the economies. Indeed, sovereign solvency becomes a problem when the level of public debt is high, especially if the states concerned do not have budgetary room to maneuver, and the growth potential is reduced. Thus, policymakers are required to take into account different determinants, the most significant, of sovereign risk allowing them to set up effective intervention policies and to act directly on these risk factors by finding the appropriate solutions to stem the effects of aggravation sovereign risk and to counter the effects of contagion and, thus, avoid an international crisis. For investors, the distinction between the determinants, which strongly explain sovereign risk, or the widening of sovereign spreads and their necessary consideration, allows them to make consistent previsions and forecasts, by carrying optimal investment strategies and, thus, maximizing the return on their portfolios. In addition, this knowledge of risk factors allows investors to reduce risk exposure and become less risk averse and less discriminating in the event of a country's sovereign insolvency and, therefore, reduce the risk of financial market instability, avoiding imminent of recurrence risk, which is inherent to vulnerable countries.

\section{REFERENCES}

Afonso, A., Arghyrou, M. \& Kontonikas, A. (2015). The determinants of sovereign bond yield spreads in the EMU. Working paper series from European Central Bank, 1781(1), 1-37. DOI: 10.2866/897469.

Allegret, J.P., Raymond, H. \& Rharrabti, H. (2016). The Impact of the Eurozone Crisis on European Banks Stocks Contagion or Interdependence?. European Research Studies Journal, 19(1), 129-148. DOI: hal-0165971.

Arellano, C., Bai, Y., \& Lizarazo, S. (2017). Sovereign risk contagion. National Bureau of Economic Research, 24031(1), 1-49. DOI : 10.21034/sr.559.

Artus, P. \& Rodado, J. C. (2012). Agences de notation : un rating ne peut pas servir à tout faire. Working paper from Natixis bank, 310(2012), 1-10.

Aizenman, J., Jinjarak, Y. \& Park, D. (2016). Fundamentals and sovereign risk of emerging markets. Pacific Economic Review, 21(2), 151-177. DOI: 10.3386/w18963.

Beirne, J. \& Fratzscher, M. (2013). The pricing of sovereign risk and contagion during the European sovereign debt crisis. Working paper series from European Central Bank, 1625(1), 1-39.

DOI : 10.1016/j.jimonfin.2012.11.004.

Canay, I. (2011). A simple approach to quantile regression for panel data. The econometrics journal, 14(3), 368-386. DOI: $10.1111 /$ j.1368-423X.2011.00349.x.

Castelletti Font, B. \& Ben Salem, M. (2017). Les déterminants des rendements souverains : le rôle des déséquilibres budgétaires et externes. Revue de la banque, 53(1), 1-5. 
Caceres, C. \& Unsal, F. (2011). Sovereign spreads and contagion risks in Asia. IMF Working paper, 11(134), 1-24. DOI: 0.1111 /asej.12012.

Chaumont, G. (2018). Sovereign debt, default risk, and the liquidity of government bonds. EconPapers, 624(1), 1-21. DOI: org/RePEc:red:sed018:624.

1Costantini, M., Fragetta, M. \& Melina, G. (2014). Determinants on sovereign bond yield spreads in the EMU: an optimal currency area perspective. European Economic Review, 70(1), 337-349. DOI: 10.1016/j.euroecorev.2014.06.004.

Corbet, S. (2014). The contagion effects of sovereign downgrades: evidence from the European financial crisis. International Journal of Economics and Financial Issues, 4(1), 83-92. DOI: //2395338.

Debarsy, N., Dossougoin, C., Ertur, C. \& Gnabo, J.Y. (2018). Measuring sovereign risk spillovers and assessing the role of transmission channels. Journal of Economic Dynamics and Control, 87(C), 21-45. DOI: 10.1016/j.jedc.2017.11.005.

De Santis, R. (2012). The euro area sovereign debt crisis. Working paper series from European Central Bank, 1419(1), 1-59. DOI: org/RePEc:ecb:ecbwps:20121419.

Ertugrul, H. M. \& Ozturk, H. (2013). The drivers of credit default swaps prices: evidence from selected emerging market countries. Emerging Markets Finance and Trade, 49(5), 228-249.

DOI: 10.2753/REE1540-496X4905S514.

Gerlash, S., Schulz, A. \& Wolff, G. (2010). Banking and sovereign risk in the euro area. Discussion paper series: Economic studies, 9(1), 1-26. DOI: RePEc:zbw:bubdp1:201009.

Hatchondo, J. C., Martinez, L. \& Onder, Y. K. (2017). Non-defaultable debt and sovereign risk. Journal of International Economics. 105(1). 217-229. DOI: 10.1016/j.jinteco.2017.01.008.

Heinz, F. F. \& Sun, Y. (2014). Sovereign CDS spread in Europe. IMF Working paper, 14(17), 1-75. DOI: http:// dx.doi.org/10.5089/9781484393017.001.

Illing, M. \& Aaron, M. (2012). Un survol des indices de propension au risque. Revue du système financier, 1, 39-45.

Kilponen, J., Laakkonen, H. \& Vilmunen, J. (2015). Sovereign risk, European crisis resolution policies and bond spreads. International Journal of Central Banking, 11(2), 285-322. DOI: org/10.2139/ssrn.

Lizarazo, S. V. (2013). Default risk and risk averse international investors. Journal of International Economics, 89(2), 317-330. DOI: 10.1016/j.jinteco.2012.08.006.

Longstaff, F. A., Pan, J., Pedersen, L. H. \& Singleton, K. J. (2011). How sovereign is sovereign credit risk? American Economic Journal: Macroeconomics, 3(2), 75-103. DOI: 10.1257/mac.3.2.75.

Manganelli, S. \& Wolswijk, G. (2009). What drives spreads in the euro area government bond market. Economic Policy, 24(1), 191-240.

Mpapalika, J. \& Malikane, C. (2019). The determinants of sovereign risk premium. Journal of Risk and Financial Management, 12(29), 1-20. DOI: 10.3390/jrfm12010029.

Niehof, B. (2014). Spillover effects in government bond spreads: evidence from a GVAR model. Joint Discussion Paper Series in Economics. 57(1), 1-35 DOI: RePEc: mar:magkse:201458.

Ordonez-Callamand, D., Gomez-Ganzalez, J.E., \& Melo-Velandia, L.F. (2017). Sovereign default risk in OECD countries: do global factors matter. North American Journal of Economics and Finance, 42(C), 629-639. DOI: $10.1016 /$ j.najef.2017.09.008

Arghyrou, M. G. \& Tsoukalas, J. D. (2011). The greek debt crisis: likely causes, mechanics and outcoms. World Economy, 34(2), 173-191. DOI: 10.1111/j.1467-9701.2011.01328.x. 


\section{FAKTORI KOJI OBRAZLAŽU SPREDOVE DRŽAVNIH SVOPOVA KREDITNIH NEIZVRŠENJA: KVANTILNI PRISTUP REGRESIJI}

\section{Rezime:}

Ovaj članak ima za cilj da analizira glavne faktore rizika koji objašnjavaju ispoljavanje i pogoršanje državnog rizika, posebno kroz dinamiku spredova državnih CDS u zemljama članicama evrozone. Faktori koji će se analizirati povezani su sa opštom averzijom prema riziku, koja se objašnjava nestabilnošću berzi, rizikom likvidnosti percipiranim fenomenom Flight to Quality, idiosinkratskim rizikom, koji se objašnjava pogoršanjem stanja makroekonomskih osnova. Usvojićemo ekonometrijski pristup metodom kvantilne regresije primenjenom na panele podataka koji je razvio Canay (2011), jer omogućava procenu uticaja nezavisnih promenljivih na različite regione distribucije, zavisne promenljive, a takođe omogućava da se prevaziđe problem prisustva ekstremnih vrednosti. Na kraju, naš model je omogućio da se vremenom i u različitim zemljama identifikuju faktori koji značajno objašnjavaju državni rizik i čije će pogoršanje verovatno dovesti do neizršavanja plaćanja, što je veoma važno znati, posebno u trenutnim nepovoljnim uslovima u makroekonomskom smislu. Tu spadaju nestablinost berzi, što ukazuje na nepoverenje investitora, smanjenje likvidnosti na tržištima obveznica, što se objašnjava fenomen Flight to Quality, budžetski faktor, koji se objašnjava neodrživim dugom i ekonomski faktor, sagledano nivoom bogatstva neke zemlje.

\section{Ključne reči:}

širenje CDS;

Suvereni rizik;

Osnove;

Averzija prema riziku; Kvantilna regresija. 